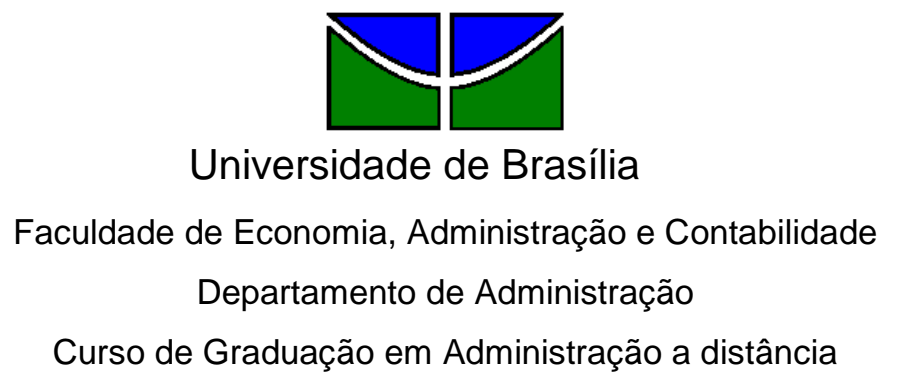

MARIA ELIETE MELO LIMA

\title{
O atual Modelo do Orçamento Participativo do Município de Rio Branco/Acre: avanço ou retrocesso?
}

Rio Branco - AC 


\section{O atual Modelo do Orçamento Participativo do Município de Rio Branco/Acre: avanço ou retrocesso?}

Monografia apresentada a Universidade de Brasília (UnB) como requisito parcial para obtenção do grau de Bacharel em Administração.

Professor Tutor: Mac Amaral Cartaxo

Professor Orientador: Msc. Riezo Silva Almeida 
Lima, Maria Eliete Melo.

O atual modelo do orçamento participativo do município de Rio Branco/Ac: avanço ou retrocesso / Maria Eliete Melo Lima. - Brasília, 2011.

$48 \mathrm{f}$ : : il.

Monografia (bacharelado) - Universidade de Brasília, Departamento de Administração - EaD, 2011.

Orientador: Prof. Msc. Riezo Silva Almeida, Departamento de Administração.

1. Orçamento Público. 2. Princípios orçamentários. 3. Orçamento Participativo. 4. Resultados e discussão. 5. Conclusões e recomendações. 


\section{O atual Modelo do Orçamento Participativo do Município de} Rio Branco/Acre: avanço ou retrocesso?

A Comissão Examinadora, abaixo identificada, aprova o Trabalho de Conclusão do Curso de Administração da Universidade de Brasília do (a) aluno (a)

\section{Maria Eliete Melo Lima}

Msc. Riezo Silva Almeida

Professor-Orientador

Msc. Alessandra Lisboa da Silva

Professor-Examinador 
Dedico este trabalho aos meus filhos, as minhas noras, a meu neto João Victor, aos colegas, especialmente, a Nadir, Raimundo Denis, Regilene, Ronildo, Ruth e principalmente, a Deus, por ter me dado forças para continuar nessa longa jornada que foi a graduação em Administração pela UNB. 


\section{AGRADECIMENTOS}

A Deus;

Aos meus filhos, Victor e Valdo Melo Lima que sempre me incentivaram a estudar;

Ao professor Msc. Riezo Silva Almeida, por ser meu orientador e indicar os melhores caminhos para a composição do trabalho;

Aos tutores que, mesmo à distância, contribuíram para a conclusão deste curso;

A todos meus familiares, que de alguma forma me incentivaram;

Aos colegas da Secretaria de Estado da Fazenda do Acre que colaboraram com o meu aprendizado;

$E$, por fim, a todos que direta ou indiretamente me ajudaram na realização deste trabalho. 
"Liderar é estabelecer uma sociedade entre o líder e sua gente." (Ken Blanchard) 
LIMA, Maria Eliete Melo. 0 atual modelo do orçamento participativo do município de Rio Branco/Ac: avanço ou retrocesso?/ Maria Eliete Melo Lima. Brasília, 2011. 50 f.: il.Monografia (bacharelado) - Universidade de Brasília, Departamento de Administração - EaD, 2011.

\section{RESUMO}

Neste trabalho, realiza-se uma análise do atual modelo do orçamento participativo do município de Rio Branco/Ac, procurando-se visualizar avanços e retrocessos proporcionados por esse modelo, além de delinear os seus contornos, de forma a localizá-lo em meio aos diversos modelos adotados no Brasil. Parte-se da premissa de Wildavsky (1992) de que a arena do orçamento é a política. Nesse sentido, o orçamento participativo (OP) representa uma nova forma de tentar superar a dicotomia Estado-sociedade civil, expressa no velho dilema proposto por Max Weber,(apud AZEVEDO; AVRITZE, 1994, p. 3) de que à crescente complexificação social seguem-se crescente burocratização/ centralização e a consequente restrição da cidadania . Por meio da identificação das características gerais da gestão democrática dos recursos públicos no Brasil, constatou-se que a gestão participativa de Rio Branco constitui-se num modelo inovador no âmbito nacional e, de fato, privilegia a participação popular. Entretanto, pela análise dos dados da percentagem do OP em relação ao Orçamento Geral da Prefeitura de Rio Branco, chegou-se à conclusão de que os percentuais destinados à gestão participativa em relação ao Orçamento Geral da Prefeitura de Rio Branco vem caindo a cada ano. Dessa forma, o atual modelo de Rio Branco deve ser aprimorado por meio de lei que torne o OP obrigatório, bem como é necessário que o Poder Municipal, no mínimo, garanta o aumento do percentual de recursos voltados ao modelo de gestão democrática dos recursos anualmente em relação ao Orçamento Geral ou pelo menos não reduza esse percentual.

Palavras-chave: Orçamento Público. Rio Branco. Participativo. 
LIMA, Maria Eliete Melo. El actual modelo de presupuestos participativos en el municipio de Rio Branco / AC: hacia adelante o hacia atrás?/ Maria Eliete Melo Lima. - Brasília, 2011. 50 f. : il.Monografia (bacharelado) - Universidad de Brasília, Departamiento de Administraçión - EaD, 2011.

\section{RESÚMEN}

En este trabajo, llevado a cabo un análisis del actual modelo de presupuestos participativos en el municipio de Rio Branco / AC, tratando de ver avances y retrocesos que ofrece este modelo, y esbozar sus contornos con el fin de localizar a los varios modelos adoptados en Brasil. Comienza con la premisa de Wildavsky (1992) que el presupuesto es el escenario de la política. En este sentido, el presupuesto participativo representa una nueva forma para tratar de superar la dicotomía entre Estado y sociedad civil, expresada en el viejo dilema propuesto por Max Weber (apud AZEVEDO; AVRITZE, 1994, p. 3), que la creciente complejidad social, seguido por aumento de la burocratización / centralización y la consiguiente restricción de la ciudadanía. Al identificar las características generales de los presupuestos participativos en Brasil, se encontró que la gestión participativa en Río Blanco en un modelo nacional innovador y, de hecho, favorece la participación popular. Sin embargo, el análisis de los datos del porcentaje de OP en relación con el presupuesto general de la Municipalidad de Río Branco, llegó a la conclusión de que los porcentajes de OP en relación con el presupuesto general de la Municipalidad de Río Branco ha ido disminuyendo cada año. Por lo tanto, la gestión participativa debe ser mejorada a través de la ley requiere que hace que el Programa Operativo, así como el gobierno de la ciudad, por lo menos, debe garantizar un aumento en el porcentaje de recursos destinados anualmente a la OP en relación con el presupuesto general o al menos no reducir este porcentaje.

Palabras-llave: Presupuesto público. Rio Branco. Participativo. 


\section{LISTA DE TABELAS E FIGURAS}

TABELA 1 - Municípios que adotaram o Orçamento Participativo no período de 1997-2000 e respectivas filiação partidária do Prefeito 33

TABELA 2 - Comparação entre a evolução da Receita do Município de Rio Branco e o percentual de participação do Orçamento Participativo entre os períodos de

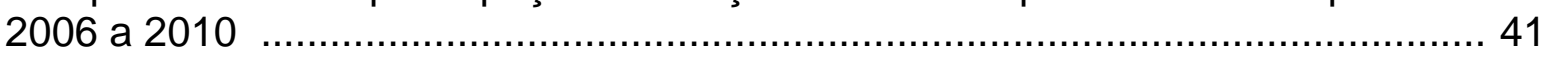

FIGURA 1 - Quadro com diversos conceitos de Orçamento Participativo 28 


\section{LISTA DE ABREVIATURAS E SIGLAS}

OGU - Orçamento Geral da União

OP- Orçamento participativo

PGP - Processo de Gestão Participativa

PT- Partido dos trabalhadores 


\section{SUMÁRIO}

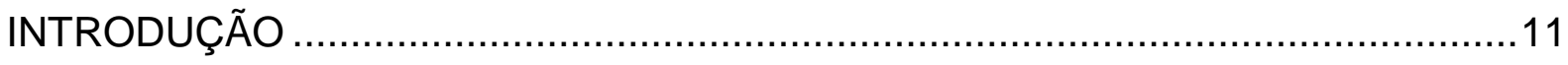

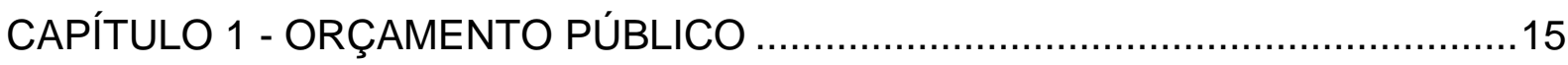

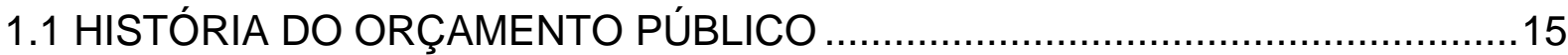

1.2 CONCEITO DE ORÇAMETNO ………………................................16

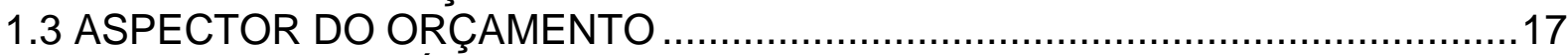

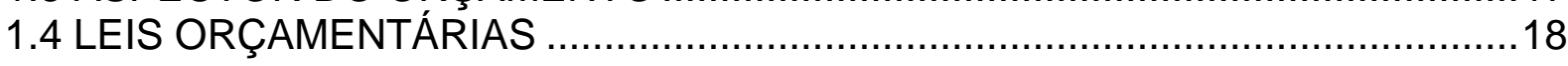

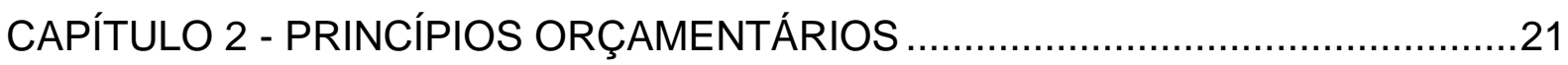

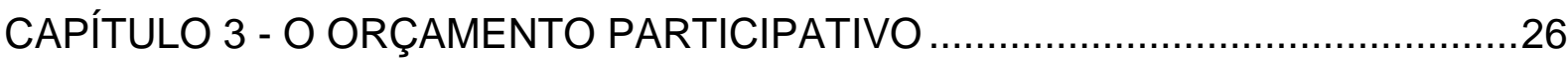

3.1 CONCEITO DE ORÇAMENTO PARTICIPATIVO …......................................26

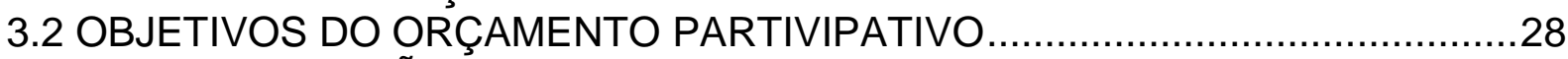

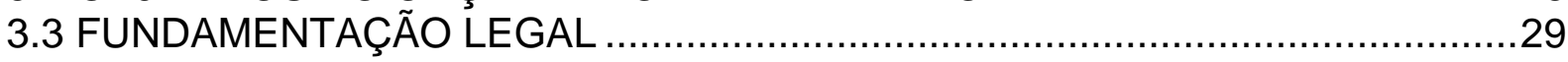

CAPÍTULO 4 - MODELOS DE ORÇAMENTO PARTICIPATIVO E O OP DE RIO BRANCO

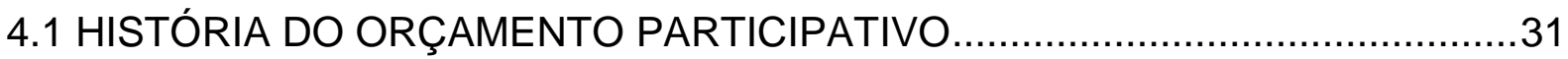

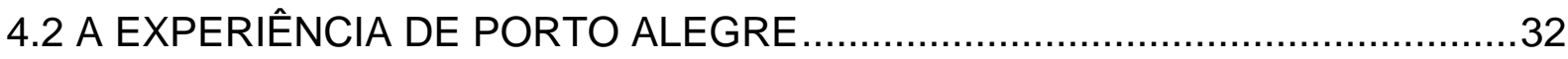

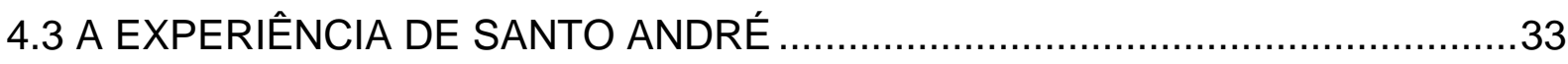

4.4 O ORÇAMENTO PARTIVIPATIVO DE RIO BRANCO/ACRE..........................34

4.4.1 A primeira experiência com o orçamento participativo de Rio Branco/Acre .....34

4.4.2 O atual processo de gestão participativa de Rio Branco/Ac............................36

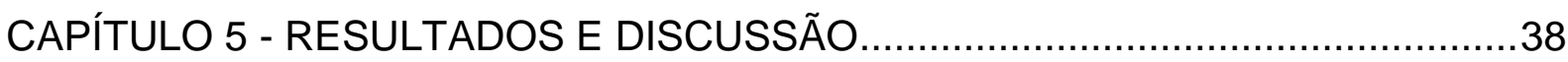

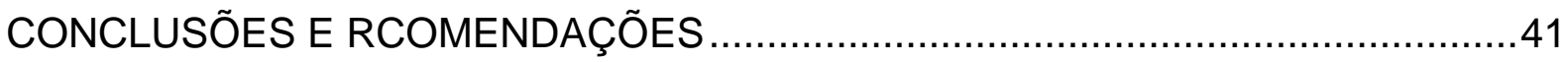

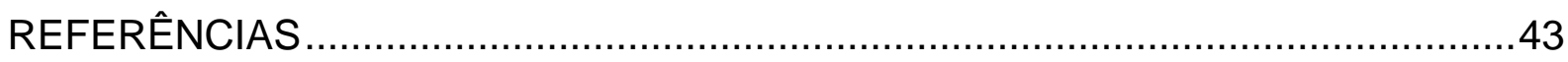




\section{INTRODUÇÃO}

O presente trabalho tem como tema 0 atual modelo de orçamento participativo do Município de Rio Branco, adentrando na área de avaliação de políticas públicas, com o objetivo de visualizar se a democracia participativa vem sendo prestigiada no atual modelo de Orçamento Participativo (OP), adotado pelo município de Rio Branco/Ac.

Orçamento Participativo (OP) é um mecanismo governamental de democracia participativa que permite aos cidadãos influenciar ou deliberar a respeito dos orçamentos públicos, geralmente sobre o orçamento de investimentos de prefeituras municipais, através de processos de participação dos cidadãos.

OP é um projeto que vem sendo amplamente debatido no meio político brasileiro desde os anos 80. A primeira experiência aconteceu em 1989, na cidade de Porto Alegre, estado do Rio Grande do Sul, sob a iniciativa do Partido dos Trabalhadores (PT) e vem sendo caracterizado pelos estudiosos como um modelo que prima pela democracia, equidade, solidariedade e eficiência. Essas características são tidas como exemplares para a análise de outros modelos de democracia participativa no Brasil (MARQUETTI, 2007).

A principal diferença entre os municípios que não adotaram e os que adotaram o Orçamento Participativo, esta na participação da população no processo de Orçamento Público, conforme atesta diversos estudos como o de Silva (2001), sobre o processo de participação social na discussão do orçamento em municípios da região metropolitana de Porto Alegre/-RS.

A maioria dos trabalhos sobre orçamento participativo voltam-se para Porto Alegre, mas já existem diversos trabalhos sobre a experiência de participação social na discussão do orçamento em diversas cidades, tais como o de Abreu (2009) que estudou o orçamento participativo de Belo Horizonte, analisando o modelo democrático adotado pela cidade.

De modo geral, os estudiosos concordam que não existe um modelo único do Orçamento Participativo, cada local implanta o seu, levando em conta as características gerais do município. Suas assembleias costumam ser realizadas em sub-regiões municipais, bairros ou distritos, em discussões temáticas e/ou 
territoriais, elegendo também delegados que representarão um tema ou território nas negociações com o governo.

Assim, diante da pluralidade de modelos de orçamento participativo adotados pelos diversos municípios brasileiros, quais as características gerais do modelo adotado pelo Município de Rio Branco/AC? Não existe ainda nenhum trabalho que procurou responde essa pergunta.

Dessa forma, neste trabalho será analisado o modelo de Orçamento Participativo adotado pela Prefeitura de Rio Branco nos anos de 2006/2011, de modo a delinear esse modelo e dizer se representa um avanço ou um retrocesso para a democracia participativa no Município de Rio Branco/Acre, especialmente em confronto com o primeiro OP de Rio Branco, datado no longínquo ano de 1992.

A partir desse objetivo geral, por meio desta pesquisa, procurou-se atingir os seguintes objetivos específicos:

- Conceituar os principais termos que fazem parte da definição do Orçamento Participativo;

- Identificar e analisar pontos positivos e/ou negativos do atual modelo adotado pelo Município de Rio Branco;

- Conhecer as principais experiências com o Orçamento Participativo no Brasil;

Para desempenhar o seu papel econômico, o Estado dispõe de vários instrumentos. Pode recorrer à intervenção direta, produzindo bens e serviços para atender necessidades coletivas ou para serem comercializados, ou pode socorrer-se de políticas econômicas.

Desde o momento em que foi introduzida a participação da população o orçamento público passou a ser diferenciado de sua conceitualização clássica, pois foi acrescentando ao material contábil a programação das ações a partir das necessidades da sociedade e tendo como objetivo a efetividade das políticas públicas.

Com base em leituras, conversas, informações e, principalmente, observação sobre as decisões tomadas através da experiência do Orçamento Participativo, chegou-se a conclusão de que é de grande valia a análise de como foi à experiência deste mecanismo no município de Rio Branco com base nos anos de 1993 e 2006/2011. Pois se sabe que um dos desafios do governante é a proporção inversa 
do número de demandas para investimentos sociais e da quantidade de recursos disponíveis pelo poder público para solução dos problemas.

Com efeito, nessa jornada, parte-se da premissa de que a arena do orçamento é a política, conforme já assinalava o mestre Wildavsky (1992). Nesse sentido, o orçamento participativo representa uma nova forma de tentar superar a dicotomia Estado-sociedade civil, expressa no velho dilema proposto por Max Weber (AZEVEDO; AVRITZER, 1994, p.3) de que à crescente complexificação social seguem-se crescente burocratização/ centralização e a consequente restrição da cidadania, tendo em vista que a burocratização gera centralização do saber e diminuição da participação popular.

Com efeito, o Estado não é apenas um sistema constitucional legal, mas é também aparelho, organização ou administração pública (BRESSER-PEREIRA, 2009). Mas a única forma de superação dessa dicotomia é a via para a racionalização da política que aponta como saída a complexificação da administração pública (AZEVEDO; AVRITZER, 1994, p.3).

Portanto, pesquisa se fundamenta com esse aporte teórico, elegendo o OP de Rio Branco como instância capaz de demonstrar ou não se o processo de democracia participativa na administração pública está se impondo na Prefeitura Municipal de Rio Branco/Ac.

Quanto às técnicas, para a elaboração da presente monografia foram utilizadas técnicas de pesquisa bibliográfica e documental.

A pesquisa bibliográfica, segundo Vergara (2004), é o estudo sistematizado desenvolvido com base em material publicado em livros, revistas, jornais, redes eletrônicas, ou seja, material acessível ao público em geral.

Com relação à pesquisa documental, foram feitas consultas às Leis Municipais e Decretos, bem como o Orçamento Geral de Rio Branco dos anos de 2005 a 2011.

Dessarte, a pesquisa teve como aporte farto acervo bibliográfico existente sobre o tema e suas variáveis, assim como de periódicos, revistas jurídicas e na internet.

A pesquisa bibliográfica foi concomitante à documental, a fim de que as informações interagissem e o escopo do presente projeto seja atingido. Terminada essa fase, iniciou-se a escritura da monografia. 
Referente à abordagem, enquadra-se como quantitativa, através de métodos estatísticos. Richardson (1999) diz que, a abordagem quantitativa representa, em princípio, a intenção de garantir a precisão dos resultados, a fim de evitar distorções de análise e interpretação, possibilitando reduzir os riscos e aumentar a margem de segurança quanto às inferências, embora não seja possível qualquer certeza absoluta. É muito utilizado nos estudos descritivos, naqueles que procuram descobrir e classificar a relação entre variáveis, bem como nos que investigam a relação de causalidade entre fenômenos.

Os dados referem-se aos períodos de 1993 e 2006 a 2011, sendo, portando um recorte condizente com a existência dos orçamentos participativos no município de Rio Branco/Acre. Assim, a escolha não foi aleatória, mas motivada.

O principal procedimento de pesquisa foi a comparação entre os diversos períodos de dados coletados, aliado da aplicação das teorias estudadas. A coleta se deu nos meses de setembro e outubro de 2011, especialmente de notícias de sítios oficiais na internet.

Para efeitos de análise os dados foram reunidos em tabelas e gráficos, realizando-se levantamentos estatístico dos dados e a pesquisa tem cunho exploratório.

Quanto à estrutura, o trabalho esta organizado em 5 (cinco) capítulos, sendo que o primeiro aborda as características gerais do Orçamento Público no Brasil, o segundo trabalha os princípios orçamentários, o terceiro procura delinear o OP no Brasil, enquanto o quarto capítulo traça alguns contornos do atual modelo de gestão participativa do município de Rio Branco. No quinto capítulo, faz-se uma discussão dos resultados, demonstrando que a gestão participativa de Rio Branco teve avanços e retrocessos, para em sede de conclusões recomendar que o OP torne-se obrigatório, bem como os recursos sejam, no mínimo, mantidos em um determinado percentual em relação ao Orçamento Geral do Município. 


\section{CAPÍTULO 1 - ORÇAMENTO PÚBLICO}

Neste capítulo, aborda-se as características gerais do Orçamento Público, sendo apresentado o seu conceito, seus aspectos, suas origens no Brasil, as leis que a regem e as demais considerações necessárias para o entendimento sobre este item.

\subsection{HISTÓRIA DO ORÇAMENTO PÚBLICO}

O sistema orçamentário funciona como uma regra que surgiu motivado pelas faltas de regras na arrecadação e aplicação de recursos, que ocasionava problemas como revoltas desde a idade média em que "um rei decidia fazer uma grande obra ou se via em dificuldades financeiras para custear uma guerra, ele estabelecia, unilateralmente, um tributo e o impunha aos habitantes do reino." (SANTOS, 2000, p. 128).

A partir da necessidade de garantir regras para evitar os excessos do rei, estabeleceu-se regras, como que a criação de tributos só poderia ser deliberada pelo parlamento e da mesma forma, a aplicação dos recursos deveria ser decidida pelo povo, representado pelo parlamento.

No entanto, apenas na Era Moderna houve o primeiro estabelecimento de regras orçamentárias, por meio da Carta Magna Inglesa. Concluindo, o orçamento surgiu para controlar os gastos dos governantes.

No entanto, nesse período ainda não havia diferenciação entre as finanças do Estado e as finanças do rei e, paulatinamente, foi se estabelecendo essa diferença, bem como a aplicação dos recursos passou a ser deliberada pelo Parlamento e não pelo rei.

Somente em 1822 "é que o Poder Executivo da Inglaterra apresentou ao parlamento um demonstrativo detalhando as receitas e despesas para o exercício" (SANTOS, 2000, p. 129). Contudo, apenas no século XX os países foram sistematicamente adotando o orçamento público, motivados pelo aumento das despesas públicas e do déficit público.

Por outro lado, o aumento dos gastos públicos possibilitou a melhoria da infraestrutura urbana, gerando a polêmica sobre o tamanho necessário ao Estado. 
Dessa forma, Santos (2000) chega à conclusão de se partiu de um modelo de orçamento voltado para o controle dos gastos reais para um orçamento mais complexo, em que atuam diversas variáveis.

O Brasil, particularmente, também passou pelas mesmas etapas do orçamento público no mundo ocidental. Na verdade o primeiro orçamento brasileiro teve origem em 1831, ainda sob a égide da monarquia e, portanto, voltado mais para o controle dos excessos reais.

Já na ocasião da Proclamação da República, os representantes do povo tiveram o poder de elaborar a proposta orçamentária e foi Criado o Tribunal de Contas da União.

Depois o orçamento regrediu passando a ser centrado no Executivo, mas se permitia aos parlamentares apresentar emendas ao orçamento desde que não implicassem em aumento de despesas.

Legalmente, o primeiro Decreto abordou a matéria orçamentária foi o Dec. 2.416 de 1940, que tratou o assunto de maneira eminentemente contábil, até que adveio a Lei 4.320/64 que trouxe como novidade o orçamento programa, mas não modificou o processo orçamentário.

Dessa forma, o orçamento tradicional do Dec. 2.416/40 foi substituído pelo orçamento programa preconizado pela lei 4.320/64. No entanto, o orçamento programa não é o objetivo do moderno orçamento público e vem sendo substituído pelo orçamento de desempenho ou resultados que preconiza os fins e não os meios de se atingir determinadas metas.

O alcance das metas estabelecidas pelo governo, portanto, hoje, é o grande desafio em matéria orçamentária, pois se tem que sopesar o tamanho necessário ao Estado para suportar demandas e a arrecadação e aplicação de recursos. Ademais, efetivamente, nunca o Estado conseguirá atender a todas as demandas.

Portanto, hoje o Estado vive num paradoxo complexo, que deve ser resolvido por meio do bom senso, procurando abordar respostas à sociedade por meio da peça orçamentária.

\subsection{CONCEITO DE ORÇAMETNO}

O termo orçamento está presente no cotidiano de todas as pessoas em diversos casos e dimensões diferenciadas, como no Governo, nas empresas, nas 
famílias, etc. O orçamento aqui tratado não se resume apenas no cálculo de estimativa de custo ou preço de um bem ou serviço. Trata-se de um todo que envolve receita e despesa.

\footnotetext{
Orçamento é o processo e o conjunto integrado de documentos pelos quais se elaboram, se expressam, se aprovam, se executam e se avaliam os planos e programa de obras, serviços e encargos governamentais, com estimativa de receita e fixação das despesas de cada exercício financeiro". (SILVA, 2004, p. 718).
}

Nos seus primórdios, o orçamento era visto apenas como previsão de receitas e despesas, de natureza contábil-financeira, mas hoje, ele possui relação direta com "planejamento" das ações do Estado, devendo interagir com essas ações. Além da previsão, possui um caráter autorizador, tendo, no Brasil, desde 1926 natureza de Lei (SANTOS, 2000).

No seu sentido mais amplo pode-se conceituar o Orçamento Público, como um documento legal, que é aprovado por lei, onde está previsto a receitas e a avaliação das despesas a serem atingidas por um Governo em um determinado exercício, geralmente de um ano.

Santos (2000, p.18) aduz que o orçamento apresenta duas funções básicas:

a) de um lado, ao definir que receitas serão arrecadadas e que despesas serão financiadas com essas receitas, o orçamento promove uma redistribuição de recursos entre os diferentes segmentos da sociedade, para o benefício de toda a coletividade; e

b) por outro lado, a definição de quem participará da elaboração do orçamento e de como se dará sua execução confere poderes políticos, sociais e econômicos a determinados atores.

Nesse aspecto, o orçamento público é fundamentalmente uma decisão política que decide sobre alocação de recursos econômicos e sociais entre segmentos da sociedade (SANTOS, 2000, p. 19).

\subsection{ASPECTOR DO ORÇAMENTO}

Com base na Lei 4.320/64, pode-se dizer que o Orçamento Público possui diversos aspectos, a saber:

1) $O$ aspecto contábil não é o único elemento do orçamento, ele também possui elementos político, econômico e jurídico. 
2) Aspecto Político - que diz respeito à sua característica de Plano de Governo ou Programa de Ação do grupo ou facção partidária que detém o Poder.

3) Aspecto Jurídico - é o que define a Lei Orçamentária no conjunto de leis do país.

4) Aspecto Econômico - é o resultado da evolução das características políticas do orçamento. Se o orçamento público é peça fundamental ao cumprimento das finalidades do Estado, não há dúvida de que deverá observar que o melhor plano é aquele que resulta numa produção com um menor gasto.

\subsection{LEIS ORÇAMENTÁRIAS}

\subsubsection{Espécies orçamentárias}

As chamadas espécies orçamentárias são modalidades de Leis orçamentárias previstas na Constituição Federal. São em número de três: Lei que institui o Plano Plurianual, Lei de Diretrizes Orçamentárias e Lei Orçamentária Anual. A seguir serão explicadas uma a uma.

Em primeiro lugar, o Orçamento Público no Brasil (Orçamento Geral da União) inicia-se com um texto elaborado pelo Poder Executivo e entregue ao Poder Legislativo para discussão, aprovação e conversão em lei. O documento contém a estimativa de arrecadação das receitas federais para o ano seguinte e a autorização para a realização de despesas do Governo. Porém, está atrelado a um forte sistema de planejamento público das ações a realizar no exercício.

O OGU é constituído de três peças em sua composição: o Orçamento Fiscal, o Orçamento da Seguridade Social e o Orçamento de Investimento das Empresas Estatais Federais.

Existem princípios básicos que devem ser seguidos para elaboração e controle dos Orçamentos Públicos, que estão definidos no caso brasileiro na Constituição, na Lei 4.320/64, no Plano Plurianual, na Lei de Diretrizes Orçamentárias e na recente Lei de Responsabilidade Fiscal.

A Constituição Federal de 1988 atribui ao Poder Executivo a responsabilidade pelo sistema de Planejamento e Orçamento, e a iniciativa dos seguintes projetos de lei: 
- $\quad$ Plano Plurianual (PPA)

- $\quad$ Lei de Diretrizes Orçamentárias (LDO)

- $\quad$ Lei de Orçamento Anual (LOA)

a) Plano Plurianual

O PPA, previsto no artigo 165, $\S 1^{\circ}$, da Constituição Federal é a lei que define as prioridades do Governo pelo período de 4 (quatro) anos. O projeto de lei do PPA deve ser enviado pelo Presidente da República ao Congresso Nacional até o dia 31 de agosto do primeiro ano de seu mandato (4 meses antes do encerramento da sessão legislativa).

De acordo com a Constituição Federal, o PPA deve conter "as diretrizes, objetivos e metas da administração pública federal para as despesas de capital e outras delas decorrentes e para as relativas aos programas de duração continuada".

b) Lei de Diretrizes Orçamentárias

A LDO, prevista no artigo 165, § 2º, da Constituição Federal é a lei anterior à lei orçamentária anual, que define as metas e prioridades em termos de programas a executar pelo Governo. O projeto de lei da LDO deve ser enviado pelo Poder Executivo ao Congresso Nacional até o dia 15 de abril de cada ano (8 meses e meio antes do encerramento da sessão legislativa).

De acordo com a Constituição Federal, 165, § 2ํㅡ, a LDO estabelece as metas e prioridades para o exercício financeiro subsequente, orienta a elaboração do Orçamento (Lei Orçamentária Anual), dispõe sobre alterações na legislação tributária e estabelece a política de aplicação das agências financeiras de fomento.

Com base na LDO aprovada a cada ano pelo Poder Legislativo, a Secretaria de Orçamento Federal, órgão do Poder Executivo, consolida a proposta orçamentária de todos os órgãos dos Poderes (Legislativo, Executivo e Judiciário) para o ano seguinte no Projeto de Lei encaminhado para discussão e votação no Congresso Nacional.

Por determinação constitucional, o Governo é obrigado a encaminhar o Projeto de Lei Orçamentária Anual ao Congresso Nacional até o dia 31 de agosto de cada ano (4 meses antes do encerramento da sessão legislativa). Acompanha 0 
projeto uma Mensagem do Presidente da República, na qual é feito um diagnóstico sobre a situação econômica do país e suas perspectivas.

c) Lei Orçamentária Anual

Prevista no artigo 165, § 5ํㅡㄹ da Constituição Federal A Lei Orçamentária Anual disciplina todos os programas e ações do governo federal no exercício. Nenhuma despesa pública pode ser executada sem estar consignada no Orçamento. No Congresso Nacional, deputados e senadores discutem na Comissão Mista de Orçamentos e Planos a proposta orçamentária (projeto de lei) enviada pelo Poder Executivo, fazendo modificações que julgar necessárias, por meio de emendas, votando ao final o projeto.

A Constituição determina que o Orçamento deve ser votado e aprovado até o final de cada Legislatura (15.12 de cada ano). Depois de aprovado, o projeto é sancionado e publicado pelo Presidente da República, transformando-se na Lei Orçamentária Anual.

A Lei Orçamentária Anual (LOA) estima as receitas e autoriza as despesas do Governo de acordo com a previsão de arrecadação. Se durante o exercício financeiro houver necessidade de realização de despesas acima do limite que está previsto na Lei, o Poder Executivo submete ao Congresso Nacional um novo projeto de lei solicitando crédito adicional.

Por outro lado, a necessidade de contenção dos gastos obriga o Poder Executivo muitas vezes a editar Decretos com limites orçamentários e financeiros para o gasto, abaixo dos limites autorizados pelo Congresso. São os intitulados Decretos de Contingenciamento, que limitam as despesas abaixo dos limites aprovados na lei orçamentária.

A Lei de Responsabilidade Fiscal, aprovada em 2000 pelo Congresso Nacional introduziu responsabilidades para o administrador público em relação aos Orçamentos da União, dos Estados e Municípios, como o limite de gastos com pessoal, por exemplo. A LRF instituiu a disciplina fiscal para os três Poderes: Executivo, Legislativo e Judiciário, estendendo também a disciplina aos Orçamentos de Estados e Municípios. 


\section{CAPÍTULO 2 - PRINCÍPIOS ORÇAMENTÁRIOS}

Princípio, de modo geral, no âmbito do direito, são fundamentos que não se confundem com regras. Um princípio também pode ser uma regra, mas nunca deve ser confundido apenas como uma regra. A diferença entre regra e princípio se dá no plano da validade. Um princípio, não se submete ao plano da validade, enquanto uma regra sim.

Quando um princípio entra em confronto com outro, pode ser preterido, porém continua válido, situando-se na questão do peso de cada princípio no caso concreto. Nas palavras de Dworkin (2002, p. 42):

quando os princípios se entrecruzam, aquele que vai resolver o conflito tem que levar em conta a força relativa de cada um. Esta não pode ser, por certo, uma mensuração exata e o julgamento que determina que um princípio ou uma política particular é mais importante que outra frequentemente será objeto de controvérsia. (DWORKIN, 2002, p. 42)

É por isso que se diz que os princípios se sopesam. Já regras, quando entram em confronto, aquelas que não são aplicadas ao caso, perdem completamente a sua validade e cria-se uma nova regra. Por isso, as regras entram na sistemática do tudo ou nada.

De modo geral, então, pode-se conceituar princípio conforme Alexy (2002, p. 99) como:

[...] os princípios são comandos de otimização que se caracterizam pelo eco de que possam ser satisfeitas em vários graus em devida medida de cumprimento não depende apenas das responsabilidades reais do jurídico, mas também [...] (ALEXY, 2002, p.99)

Tratando da diferenciação entre princípios e regras, o mesmo Alexy (2002, p.99) sintetiza a diferença:

Em contraste, as regras podem ser aplicadas ou não [...] Em certas circunstâncias, um princípios precede o outro. Sob outras circunstâncias, a precedência pode ser resolvida em sentido inverso. Isto é o que eu quero dizer em casos específicos os princípios têm diferentes pesos e prima o Princípio com mais peso. Conflitos de regras são executadas em dimensão de validade, colisão de princípios - como só podem entrar em colisão princípios válidos, ocorrerá além da dimensão de validade, na dimensão do peso $^{1}$ (tradução livre) (ALEXY, 2002, p.99)

1

$1 \quad$ [...]Los princípios son mandatos de optimizacion que están caracterizados por el echo de que pueden ser cumplidos em diferente grado em que la medida devida de su cumplimiento no solo depende de las responsabilidades reales sino también de las jurídicas [...]Em cambio, las 
Rodrigues (2009), citando Canotilho, distingue três categorias de princípios: os estruturantes que se referem à estrutura do Estado; os gerais relativos às garantias individuais e coletivas previstas no art. 5ํ da Constituição Federal de 1988; e os específicos, que orientam determinada ciência.

Os princípios orçamentários são aqueles que voltam-se para a peça orçamentária e são encontrados na Constituição Federal de forma expressa ou implícita. Os princípios constitucionais orçamentários podem ser divididos em:

- Unidade - Previsto no artigo 165, $§ 5 .^{\circ}$, da Constituição Federal, este princípio prescreve que o orçamento deve ser uno, ou seja, deve existir apenas um orçamento para dado exercício financeiro e para cada unidade da federação (SANTOS, 2000, p. 44). Na verdade, esse princípio não significa que deva existir um único documento orçamentário, pois na atualidade, hoje a peça orçamentária é composta por inúmeros documentos. A unidade, portanto, se refere mais a orientação política da peça orçamentária, que permite ao legislativo obter eficazmente um retrato geral das finanças públicas e, exercer um controle racional e direto das operações financeiras de responsabilidade do Executivo;

- Totalidade - Conforme já exposto, o princípio da Unidade refere-se à orientação, cabendo à doutrina tratar de reconceituar o princípio da unidade de forma que abrangesse as novas situações. Surgiu, então, o princípio da totalidade, que possibilitava a coexistência de múltiplos orçamentos que, entretanto, devem sofrer consolidação, de forma a permitir uma visão geral do conjunto das finanças públicas (AZEVEDO FILHO, 2011, p.01);

- Universalidade - Princípio pelo qual o orçamento deve conter todas as receitas e todas as despesas do Estado, inclusive, "englobando todos os Poderes, os fundos, os órgãos e as entidades da Administração Pública" (SANTOS, 2000, p.44). Indispensável para o controle parlamentar.

- Anualidade ou Periodicidade - Previsto no artigo 48, inciso II, artigo 165, inciso III e $\S 5$. , e artigo 166 da Constituição Federal é um dos princípios

reras son normas que solo pudem ser cumplidas ou no [...] Bajo ciertas circunstancias, uno de los princípios precede al otro. Bajo otra circunstancias, la precedencia puede ser solucionada de manera inversa. Esto es lo que quiere decir que em los casos concretos los princípios tienen diferentes pesos y que prima lo princípio com mayor peso. Los conflictos de reglas se llevan a cabo em la dimenson de validez, la conlision de princípios - como solo pudem entrar em colision princípios validos- tienen lugar mas allá de la dimension de la validez, en la dimension del peso. 
orçamentários mais antigos no Brasil. Segundo Bulos (2001. p. 1109) "O vetor da anualidade orçamentária, também conhecido por antonomásia, princípio da lei ânua, nasceu do expediente político de se obrigar os monarcas a convocarem o parlamento, pelo menos, uma vez por ano. Vigora entre nós desde a Constituição Imperial de 1824". Reza o princípio que o orçamento deve ser elaborado e autorizado para um determinado período de tempo, geralmente um ano. Os "e os correspondentes créditos orçamentários devem ter sua vigência adstrita ao exercício financeiro" (SANTOS, 2000, p. 44). A exceção se dá nos créditos especiais e extraordinários autorizados nos últimos quatro meses do exercício, reabertos nos limites de seus saldos, serão incorporados ao orçamento do exercício subsequente. No Brasil, a lei que rege o período é a 3.420/64, que estabelece que o o exercício financeiro vai de 1. de janeiro a 31 de dezembro (AZEVEDO FILHO, 2011, p.01);

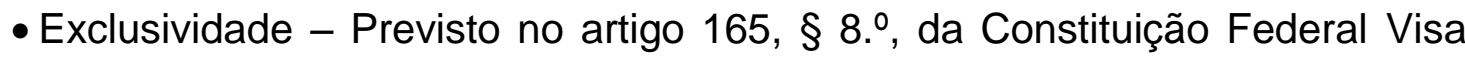
evitar que matérias estranhas ao orçamento sejam incorporadas na peça orçamentária, como forma de subterfúgio do governo para "empurrrar, sorrateiramente, outros temas". A lei orçamentária deverá conter apenas matéria orçamentária ou financeira. Na Constituição Federal há apenas uma exceção a esse princípio que é a autorização para abertura de créditos suplementares e contratação de operações de crédito, "ainda que por antecipação de receita", como consta da parte final do $\S 8 .^{\circ}$ do artigo 165 ;

- Especificação, Especialização ou Discriminação - Nas palavras de Santos (2002) este princípio reza que a LOA não poderá consignar dotações globais a despesas, devendo fornecer detalhamento suficiente para demonstrar a origem e a aplicação dos recursos;

- Programação: determina que as receitas e despesas devem estar ligadas ao planejamento estatal, isto é, "deverão ser organizadas de modo a veicular a programação de trabalho do governo, seus objetivos, suas metas e suas ações" (SANTOS, 2000, p. 44). Dessa forma, o orçamento deve ter forma de programação. Nas palavras de Bulos (2001, p.1109):

O orçamento-programa derivou da concepção de se criar um orçamento que interferisse na reestruturação da economia estatal. Isto porque o orçamento clássico não objetivava promover a ação direta do Estado na economia. Mas com a crise econômica de 1929, que significou a grande depressão norte-americana da época, e com o término da Segunda Grande Guerra Mundial, o binômio orçamento público e economia nacional passou a se conectar, devido à necessidade de planejamento, 
reestruturação e programação da atividade governamental. Por conseguinte, a noção clássica de orçamento, que preconizava a assertiva "equilibrar para crescer financeiramente", cedeu lugar a uma concepção ampla de orçamento, equacionando realidade orçamentária e técnica de planejamento. Surgia, assim, o orçamento-programa, aqui compreendido como a espécie ou variedade do gênero orçamento, cuja tarefa é programar e planejar a atividade econômica e a ação governamental do Estado, fomentando o crescimento das entidades político-administrativas de direito público interno (BULOS, 2001, p. 1109)

Assim, esse princípio se aplica a todos os poderes e entes federativos, fazendo a interação entre os diversos planos e ações do governo;

- Não Vinculação ou Não Afetação das Receitas - Nenhuma parcela da receita geral poderá ser reservada ou comprometida para atender a certos casos ou a determinado gasto. Ou seja, a receita não pode ter vinculações.

as receitas constantes da LOA deverão estar livres de comprometimento prévio a determinados gastos, sendo vedada avinculação de receitas de impostos a órgão, fundo ou despesa. (SANTOS, 2000, p. 45)

Essa vedação decorre do fato de qualquer afetação de receitas reduz o grau de liberdade do gestor e engessa o planejamento de longo, médio e curto prazo.

- Orçamento Bruto - Este princípio clássico surgiu juntamente com o da universalidade, visando ao mesmo objetivo. Todas as parcelas da receita e da despesa devem aparecer no orçamento em seus valores brutos, sem qualquer tipo de dedução. A intenção é a de impedir a inclusão de valores líquidos ou de saldos resultantes do confronto entre receitas e as despesas de determinado serviço público. (SANTOS, 2000, p. 44);

- Equilíbrio - Para Santos (2000, p.44) este princípio prescreve que as receitas constantes da LOA não devem exceder as despesas previstas para 0 exercício financeiro. Este Princípio clássico que tem merecido maior atenção, mesmo fora do âmbito específico do orçamento, pautado nos ideais liberais dos economistas clássicos (Smith, Say, Ricardo). No passado foi tido como a regra de ouro das finanças públicas, tendo em vista que visa que o Estado não contraía dívidas que não possa pagar (SANTOS, 2000, p. 45) ou para simples despesas correntes;

- Legalidade - Princípio basilar para a Administração Pública brasileira, sendo o art. 37 da Constituição Federal, aplica-se também às leis orçamentárias. Aliás, historicamente, sempre se procurou dar um cunho jurídico ao orçamento, ou seja, para ser legal, tanto as receitas e as despesas precisam estar previstas na Lei 
Orçamentária Anual, ou seja, a aprovação do orçamento deve observar processo legislativo porque se trata de um dispositivo de grande interesse da sociedade;

- Publicidade - O conteúdo orçamentário deve ser divulgado (publicado) nos veículos oficiais de comunicação para conhecimento do público e para eficácia de sua validade. O princípio da Publicidade se aplica a toda a Administração Pública, consoante o art. 37 da Constituição Federal, sendo uma obrigação e não uma mera liberalidade do gestor público;

- Clareza ou Objetividade - O orçamento público deve ser apresentado em linguagem clara e compreensível a todas as pessoas que, por força do ofício ou interesse, precisam manipulá-lo. Difícil de ser empregado em razão da facilidade de a burocracia se expressar em linguagem complexa;

- Exatidão - De acordo com esse princípio as estimativas devem ser tão exatas quanto possível, de forma a garantir à peça orçamentária um mínimo de consistência para que possa ser empregada como instrumento de programação, gerência e controle. $O$ ferimento deste princípio vem acarretando alguns problemas como superestimação de receitas, contingenciamento de despesas, anulação de valores empenhados, instituição de fundos. Por isso, é um princípio muito importante, pois o executivo tende a querer "iludir" os outros poderes para ficar com a maior parte das receitas.

- Transparência e participação: Nas palavras de Santos (2000, p. 44) este principio aponta que "os planos, os orçamentos, as LDO; as prestações de contas e os relatórios de execução orçamentária devem ser instrumentos de transparência da gestão fiscal, devendo o processo orçamentário incentivar a participação popular". 


\section{CAPÍTULO 3 - O ORÇAMENTO PARTICIPATIVO}

Neste capítulo procura-se delinear o orçamento participativo no Brasil, a fim de conhecê-lo melhor. Dessa forma, nos subitens a seguir será apresentado o conceito, os objetivos e a fundamentação legal do Orçamento Participativo.

\subsection{CONCEITO DE ORÇAMENTO PARTICIPATIVO}

O Orçamento Participativo tem se mostrado como um instrumento de participação popular ativo, na medida em que permite a participação direta do povo nas deliberações e tomada de decisão quanto às formas mais eficazes e eficientes de aplicação dos recursos públicos.

Para Dutra e Benevides (2001), o Orçamento Participativo é um processo de aprofundamento da democracia direta e reflete o início da construção do socialismo.

Por isso, para Ananias (2005) o Orçamento Participativo torna-se assim uma escola de formação política e de reconhecimento do poder de transformação social.

Entretanto, Ribeiro (2005) menciona que, em experiência do OP da Habitação em Belo Horizonte, Minas Gerais, parcela significativa dos coordenadores do núcleo, revestida do papel de liderança política, estavam reproduzindo com muita destreza a cultura política tradicional, justamente a que eles estavam imbuídos de combater: 0 clientelismo político, o mandonismo e a política do favor. Eles estavam reconhecendo as possibilidades do "cargo" que Ihes dariam oportunidade de acesso, utilizaram-se de códigos de autoridade e poder, visando ampliar seu prestígio como liderança comunitária e/ou angariar benefícios pessoais.

Por isso, há diversos posicionamentos contrários ao OP e Sanchez (2002) os elenca:

a) os cidadãos, de fato, não querem participar: os cidadãos não querem se envolver realmente no processo complicado e cansativo que caracteriza qualquer tomada de decisões públicas;

b) os cidadãos, quando participam, o fazem de uma forma muito inconstante: não se pode garantir regularidade na presença dos cidadãos nas reuniões do orçamento participativo; 
c) os cidadãos dispostos a participar são sempre os mesmos: os cidadãos potencialmente capacitados ou dispostos a participar acabam constituindo uma pequena minoria que sempre está presente;

d) os cidadãos que se mobilizam e pretendem participar, muitas vezes, só representam a si próprios e a seus interesses: normalmente, os cidadãos que costumam mobilizar-se defendem interesses muito particulares.

No entanto, o OP é uma prática muito recente e que necessita de amadurecimento na própria forma de fazer política e seus objetivos são muito interessantes para a democracia.

\begin{tabular}{|c|c|c|}
\hline Definiçōes de Orçamento Participativo & Obra & Idéia-chave \\
\hline $\begin{array}{l}\text { "'mecanismo de gestão democrática e participativa das } \\
\text { políticas públicas para decidir a melhor alocação dos } \\
\text { recursos". }\end{array}$ & $\begin{array}{l}\text { Sánchez } \\
(2002, \text { p.13) }\end{array}$ & $\begin{array}{l}\text { Gestão } \\
\text { democrática } \\
\text { participativa }\end{array}$ \\
\hline $\begin{array}{l}\text { "modalidade alternativa de tratamento dos recursos } \\
\text { públicos, por introduzir a população no processo de } \\
\text { discussão e definição da peça orçamentária municipal". }\end{array}$ & $\begin{array}{l}\text { Borba e } \\
\text { Lüchmann } \\
(2007, \text { p. 24) }\end{array}$ & $\begin{array}{l}\text { Alternativa de } \\
\text { tratamento dos } \\
\text { recursos públicos }\end{array}$ \\
\hline $\begin{array}{l}\text { "é uma inovação institucional que representa uma nova } \\
\text { forma de combinar democracia com a definição das } \\
\text { políticas públicas". }\end{array}$ & $\begin{array}{l}\text { Marquetti } \\
(2008, \text { p.53) }\end{array}$ & $\begin{array}{l}\text { Inovação } \\
\text { institucional } \\
\text { (democracia e } \\
\text { definição de } \\
\text { politicas públicas) }\end{array}$ \\
\hline $\begin{array}{l}\text { "um modelo de partilha do poder politico mediante uma rede } \\
\text { de instituiçőes democráticas orientadas para obter decisões } \\
\text { por deliberação, por consenso e por compromisso". }\end{array}$ & $\begin{array}{l}\text { Santos } \\
(2002 \\
526)\end{array}$ & $\begin{array}{l}\text { Partilha do poder } \\
\text { politico }\end{array}$ \\
\hline $\begin{array}{l}\text { "adoção de práticas diferenciadas de gestão orçamentária } \\
\text { municipais, nas quais o ingrediente inovador anunciado } \\
\text { consiste na abertura de canais e mecanismos de } \\
\text { participação popular no processo de destinação dos } \\
\text { recursos públicos das prefeituras" }\end{array}$ & $\begin{array}{l}\text { Pires (2001, } \\
\text { p. } 77)\end{array}$ & $\begin{array}{l}\text { Abertura de canais } \\
\text { de participação } \\
\text { popular }\end{array}$ \\
\hline $\begin{array}{l}\text { "é uma decisão politica, mas que implica um círculo virtuoso } \\
\text { politico, democrático e técnico também, em que a relação } \\
\text { de todas estas partes e a construção de um planejamento } \\
\text { participativo constituem o eixo central de todo o processo". }\end{array}$ & $\begin{array}{l}\text { Lemos }(2005 \text {, } \\
\text { p. } 24)\end{array}$ & $\begin{array}{l}\text { Decisão politica e } \\
\text { planejamento } \\
\text { participativo }\end{array}$ \\
\hline
\end{tabular}

Sistemantizando diversos conceitos de OP, Rego (2009, p. 49) elaborou o seguinte quadro: Figura 1

Fonte: (REGO, 2009, p. 49)

De acordo com as diversas definições esboçados no trabalho de Rego (2009), a pesquisadora apontou como ponto em comum entre as definições colacionadas por ela, os seguintes pontos em comum: participação popular, governo, democracia, repartição do poder político e planejamento da gestão. De modo geral, as definições colacionadas nesta monografia possuem também as mesmas características em 
comum apontadas por Rego, logo, pode-se concluir que os doutrinadores concordam em diversos pontos, embora não haja absoluto consenso entre eles.

\subsection{OBJETIVOS DO ORÇAMENTO PARTIVIPATIVO}

Orçamento Participativo tem como principal objetivo ser um instrumento de democratização, que visa assegurar a participação direta da população na definição das prioridades para os investimentos públicos, procurando romper com a tradição até então existente de apenas os governantes tomarem suas decisões, deixando os interesses da população de lado.

Independentemente da forma de implantação adotada do OP, os objetivos essenciais pretendidos pelo Poder Executivo Municipais, segundo Luiz Menezes Azevedo filho (2011), basicamente, são:

a) Com a participação direta da população, pretende-se melhor definir as prioridades essenciais para os investimentos públicos dos bairros;

b) Aumentar a responsabilidade dos gestores públicos para com a população por ele administrada, de modo que corresponda aos anseios por ela invocados;

c) Diminuir um pouco o poder de decisão de prefeitos e vereadores, e assim abrir espaço, para que a população também possa opinar sobre a aplicação das verbas públicas;

d) Entre outros casos, o orçamento participativo, também teria o intuito de diminuir a corrupção que afeta os órgãos públicos em nosso país, já que a população passaria a fiscalizar a destinação dos recursos do município.

Entre tantos objetivos que cercam o orçamento participativo, o que de fato é mais importante e que talvez represente a essência de todo o processo seja a mudança cultural de participação que promove nas pessoas e nas instituições, instituindo um novo consenso sobre como viver numa sociedade que se quer democrática. Felizmente, nos últimos anos, com o aperfeiçoamento dos mecanismos de controle democrático da gestão pública, os administrações públicos vêm adotando uma nova postura diante das problemáticas da democracia e da cultura política no Brasil e eles mesmos vêm mudando, devido à necessidade de se adequarem ao novo perfil de administrador público exigido pela população. 


\subsection{FUNDAMENTAÇÃO LEGAL}

A Constituição de 1988 em prol do exercício da democracia e da soberania popular compatibilizou, no seu art. $1^{\circ}$, a existência da democracia representativa e da democracia participativa, sem exclusão ou concorrência, mas complementar e harmônica.

Art. $1^{\circ}$, parágrafo único. "Todo poder emana do povo, que o exerce por meio de representantes eleitos ou diretamente, nos termos desta Constituição". (BRASIL, 2011, p. 04)

$\mathrm{Na}$ verdade, na Constituição não há qualquer menção direta ao orçamento participativo, mas esse deflui da interpretação de diversos dispositivos da Constituição Federal, tais como o art. 14, que trata da soberania popular, verbis:

Art.14. "A soberania popular será exercida pelo sufrágio universal e pelo voto direto e secreto, com o valor igual para todos, e, nos termos da lei, mediante" (BRASIL, 2011, p. 04).

O art .29 da Constituição Federal de 1988, nos seus incisos XII e XIII, destacam a participação popular em questões orçamentárias, estabelecem a cooperação das associações representativas no planejamento municipal, bem como determina competência para que os municípios, por meio de suas leis orgâncias, normatizem tais dispositivos (REGO, 2011, p. 49).

Em nível infraconstitucional, o OP é fundamentado em diversas leis, como o Estatuto da Cidade, (Lei Federal oㅜ 10.257, de 10 de julho de 2001), em nível federal e nas Leis Orgânicas dos municípios que o adotaram. Além disso, a participação democrática é preconizada em diversas leis, tais como:

$\Rightarrow$ LCs 64/90; 81/94 - Legislação de inelegibilidade.

$\Rightarrow$ Lei 4737/65 - Código Eleitoral.

$\Rightarrow$ Lei 9504/97 - Estabelece normas para as eleições.

$\Rightarrow$ Lei 9709/98 - Regulamenta o disposto nos incisos I-III do caput".

O orçamento participativo é, enfim, uma oportunidade para a tomada de consciência que abre alas para a cidadania, assim como para a exorcização do populismo, que tão mal fez e faz a ela.

O grande problema, segundo Sanchez (2002) é que a lei faculta ao gestor público adotar ou não o $\mathrm{OP}$, advindo daí uma disparidade entre a prática e o espírito democrático da Constituição Federal de 1988. 
Dessa forma, Ananias (2005) afirma que o nível de democracia de um município é representado no seu OP, pois o OP é o canal comunicativo em que os diversos segmentos sociais esboçam seus anseios e preocupações para o poder público. Nesse aspecto, o orçamento participativo representa um amadurecimento cultural da Administração Pública e da população. 


\section{CAPÍTULO 4 - MODELOS DE ORÇAMENTO PARTICIPATIVO E O OP DE RIO BRANCO}

\subsection{HISTÓRIA DO ORÇAMENTO PARTICIPATIVO}

As primeiras experiências com o OP surgiram na Europa, em prefeituras de cidades como Bolonha na Itália e Delf, (na Holanda), Chambéry (na França), Barcelona (na Espanha), e nas duas últimas décadas, também na América do Norte, em Ontário no Canadá, em Portland, em Auburn e no Estado de Minesota, nos Estados Unidos da América. Todos inovavam, convidando os habitantes a participar das decisões urbanas (NUNES, 1999; PIRES, 2001).

A gestão democrática, portanto, estabeleceu-se como base nos locais em que a democracia se consolidou há mais tempo. Relata Saruê (2002) que em Monique (Holanda), existem organizações de vários bairros que compõem um conselho e os projetos só vão à Câmara Municipal se antes tiverem sido aprovados pela comunidade, por meio dos conselhos.

Outro exemplo é Nova lorque, em que mais de trinta Organizações Não Governamentais participam da gestão das regiões em que a cidade é dividida para efeitos de administração.

Em termos de Brasil, por mais incrível que pareça, as primeiras experiências surgiram sob a égide da Ditadura Militar em cidades como em Ipiaú/Bahia nos anos 60, Piracicaba/SP e Boa Esperança/ES na década de 70 e Vila Velha/ES, Pelotas/RS e Lages/SC41 na década de 80 (ALVES, 1980; SOUZA, 2000; SILVEIRA, 2000).

Como instrumento institucionalizado, no entanto, o OP surge efetivamente na década de 80 como forma de luta contra o regime ditatorial, especialmente bancado pelo partido MDB (Movimento Democrático Brasileiro). Depois, o Partido dos Trabalhadores assumiu a defesa do OP por motivos distintos do MDB.

$\mathrm{O}$ viés petista apontada o OP não apenas como sinônimo de resistência à ditadura, mas como elemento estrutural da democracia, tendo, portanto, origem genética. A experiência petista considerada de maior sucesso foi com a Prefeitura de Porto Alegre, a qual foi copiada por outras administrações no Brasil inteiro como Belo Horizonte, São Paulo, etc, com algumas diferenças, é óbvio. 
Segundo dados colacionados por Sanchez (2002) a maioria dos OPs foram criados em governos de esquerda:

\begin{tabular}{|c|c|}
\hline Partidos Políticos dos prefeitos Municípios & Número de municípios \\
\hline PT & 52 \\
\hline PSDB & 13 \\
\hline PSB & 11 \\
\hline PMDB & 09 \\
\hline PDT & 08 \\
PV & 03 \\
\hline PPS & 03 \\
PFL & 02 \\
PTB & 02 \\
& \\
\hline
\end{tabular}

Fonte: Pesquisa FNPP, 2001 e IBGE apud Sanchez (2002)

TABELA 1- Municípios que adotaram o Orçamento Participativo no período de 1997-2000 e respectivas filiações partidárias dos Prefeitos.

Com efeito, a proposta petista não se baseava em experiências já realizadas, mas nas comunas de Paris, pretendendo fazer uma transferência de poder para a classe trabalhadora organizada. (GENRO, 1997). Dessa forma, na verdade, o próprio PT não sabia quais os efeitos da OP na vida pública brasileira.

No entanto, a experiência de Porto Alegre foi tão bem sucedida em termos de intervenção urbana que foi selecionada pelas Nações Unidas como uma das quarenta melhores intervenções urbanas do mundo, sendo merecedora de apresentação, em 1995, na segunda Conferência Mundial sobre Habitação Humana (Habitat II), realizada em Istambul. Assim, Porto Alegre tornou-se referência mundial de boa prática orçamentária e democrática (FEDOZZI, 2000; FERNANDES, 2000; PIRES, 2001; SANTOS, 2002).

Nesse aspecto, vale melhor entender a experiência de Porto Alegre e algumas outras realizadas no Brasil, como a de Santo André.

\subsection{A EXPERIÊNCIA DE PORTO ALEGRE}

Tida como experiência mais bem sucedida em termos de Brasil, o OP de Porto Alegre é uma experiência iniciada em 1989 e que foi, aos poucos se 
afirmando, se tornando cada vez mais concorrido e complexo. Segundo Bosi (2007) o OP de Porto Alegre constitui-se numa engenharia política complexa e sofisticada, abrangendo critérios matemática na distribuição de recursos, com o objetivo de contemplar as áreas mais carentes e populosas.

No OP de Porto Alegre, a cidade foi dividida em 16 regiões, conforme a geografia e as afinidades culturais. A população de cada região elege quatro prioridades entre oito possíveis abrangendo temas como saúde, educação, saneamento básico, habitação, transporte e circulação, organização da cidade e pavimentação. Além disso, dentro de tema prioritário eleito, a população hierarquiza as obras conforme a sua importância (BOSI, 2007, p. 51.)

O índice de realização das obras previstas no OP chegou a impressionantes percentagens acima de $80 \%$, o que deu credibilidade ao OP, o qual passou a ter maior participação popular ao longo dos anos (BOSI, 2007, p. 53).

Além disso, Bosi (2007) credita o sucesso do OP de Porto Alegre devido aos critérios de distribuição dos recursos do OP, quais sejam: densidade populacional, carência de infraestrutura e poder aquisitivo da população.

Com efeito, no período de nove anos, entre 1991 e 2000, os investimentos nas regiões mais pobres de Porto Alegre foram maiores que em outras regiões, de forma que $35 \%$ dos investimentos recaíram nas áreas mais pobres. Aliás, o montante dos recursos reservados ao OP aumentou de 10\% em 1990 para 17\% em 1992.

\subsection{A EXPERIÊNCIA DE SANTO ANDRÉ}

Santo André é considerada também uma das cidades pioneiras no Orçamento Participativo no Brasil. Contudo, seu modelo difere bastante de Porto Alegre. Santo André criou uma instância decisória denominada Núcleo de Participação Popular (NPP) no qual um munícipe se encarrega de coordenar o OP. Esse núcleo possui "agentes de participação popular que desenvolvem diversos tipos de projetos em diversas secretarias". (BOSI, 2007, p. 59)

Assim como Porto Alegre, a cidade foi dividida em 18 regiões, de acordo com critérios geográficos e culturais, que elegem prioridades nos temas de saúde, educação, habitação, saneamento, etc. 
No entanto, o Conselho do OP é paritário, isto é, para cada membro da sociedade civil há um membro do poder público. (SANCHEZ, 2002, p. 45).

Reunindo as características desses dois modelos, Sanchez (2002) elenca as características dos Ops no Brasil como sendo a adoção de critérios técnicos e políticos para a distribuição de recursos, como critérios demográficos, de carência territorial de bens, dos serviços públicos, etc. Disserta, ainda, que o que caracteriza a natureza e o perfil de um OP é a concretização dos princípios da:

decisão e soberania popular, materializada na noção de deliberação pública, com o governo assessorando e promovendo de forma ativa a execução da política participativa; 2) a decisão sobre o conjunto do orçamento da prefeitura; 3) accountablity ou prestação de contas e transparência para a efetivação do controle social das decisões; e 4) delimitação de um processo de decisão, por parte da sociedade e do Estado, de um corpo de representantes especialmente eleitos para deliberar a alocação dos recursos públicos, que além de tudo se auto-regulamenta. (SANCHEZ, 2002, p. 44)

Dessa forma, o OP necessita ter uma adequada associação entre técnica e ação política. Além disso, vislumbra-se que o OP no Brasil está diretamente associado às experiências petistas nos governos municipais, que só pode ser desenvolvida sob a égide do contexto pós-ditadura militar.

\subsection{O ORÇAMENTO PARTIVIPATIVO DE RIO BRANCO/ACRE}

O Orçamento Participativo será caracterizado, visualizando-se os contornos da gestão participativa no município de Rio Branco/AC. Para tanto, elegeu-se como ponto de partida a primeira experiência do OP para depois o trabalho se centrar no atual modelo de gestão participativa.

\subsubsection{A primeira experiência com o orçamento participativo de Rio Branco/Acre}

O primeiro orçamento participativo em Rio Branco nasceu no governo do Petista Jorge Viana em 1993, segundo o estudo de Cordovil (2006 apud XANGAI, 2006) e foi marcado por uma ampla discussão com a sociedade civil. Segundo Cordovil (2006 apud XANGAI, 2006) não há dados guardados pela Prefeitura 
Municipal de Rio Branco a respeito da elaboração ou da execução do Orçamento Participativo, por isso seu estudo baseou-se em matérias publicadas nos jornais Página-20, O Rio Branco e A Gazeta, além de atas e documentos guardados pelo movimento comunitário.

Cordovil (2006) afirma que no início as reuniões aconteciam para selecionar as necessidades essenciais do próprio bairro o que os levava a apontar as soluções mais urgentes. A partir daí, então, aconteciam as plenárias regionais onde as reivindicações iam sendo triadas com apoio de assessores municipais a fim de formar o documento final que era apresentado ao prefeito com as reivindicações que a população esperava ver atendidas no ano seguinte.

Ressalte-se, porém, que a divisão das discussões dos problemas regionais por bairro já existia antes do governo petista, porém de forma clientelista, pois não eram levadas a sério pela administração municipal (CORDOVIL, 2006, apud XANGAI, 2006).

Com o advento do governo petista na capital acriana, os bairros da cidade foram divididos em 16 regionais, que foram se juntando até restarem apenas seis abrangendo toda a cidade.

Contudo, o orçamento participativo não foi realizado em todos os bairros (CORDOVIL, 2006 apud XANAGI, 2006) havendo níveis diferentes de avanços. No Bairro Conquista, por exemplo, todas as ações previstas foram realizadas, enquanto em outros Bairros como o Preventório a vontade da comunidade não foi realizada.

Cordovil (2006 apud XANGAI, 2006) então, conclui que uma das grandes falhas daquele orçamento participativo é o fato de não ser impositivo, não ser uma lei que obriga o administrador público. Nesse aspecto, no período do governo de Mauri Sérgio, que substitui Jorge Viana, o orçamento participativo deixou de ser uma prática e houve um grande retrocesso.

O governo seguinte, de Flaviano Flávio Batista de Melo, do Partido do Movimento Democrático Brasileiro (PMDB) durou menos de dois anos e foi sucedido por seu vice Isnar Leite que também não deu continuidade na experiência do OP em Rio Branco.

O governo de Isnard Leite foi sucedido em 2004 pelo de Raimundo Angelim, do Partido dos Trabalhadores e, novamente o OP ganhou importância, sendo ressuscitado e ganhando contornos mais definidos. 


\title{
4.4.2 O atual processo de gestão participativa de Rio Branco/Ac
}

O Governo Angelim dividiu a cidade em sete regionais administrativas por meio da lei 1.551/2005 e essas regionais passaram a ser responsáveis pela organização, acompanhamento e desenvolvimento das políticas públicas, bem como a organização das discussões regionais sobre o OP:

\begin{abstract}
Art. 88. Às Regionais Administrativas caberá coordenar e acompanhar a implementação das políticas públicas de desenvolvimento municipal, no nível regional, visando à eficiência, eficácia e efetividade na prestação dos serviços, na melhoria da qualidade de vida da população, na gestão democrática dos recursos públicos e na garantia do controle social.
\end{abstract}

Art. 89. As Regionais Administrativas terão suas estruturas implantadas por Decreto, de forma gradual e compatível com o grau de complexidade adquirido pelas ações regionalizadas. (RIO BRANCO, 2011, p. 11)

Por meio do Decreto no 2730 de 05 de maio de 2008, nos termos da lei municipal 1.551/2005, nomeou os membros dos conselhos administrativos regionais, responsáveis, sendo que os membros comunitários eram eleitos pela própria comunidade.

Cada regional possui seu conselho com membros de segmentos distintos. São os seguintes segmentos: Segmento da Juventude, Segmento do Movimento Comunitário, segmento da Arte Cultura e Esporte, Comunidades Afro Descendentes, Segmento das Mulheres, Segmento da Saúde, Segmento das Lideranças Tradicionais, Segmento das Entidades - União Municipal das Associações de Moradores de Rio Branco - UMAMRB, Segmento de Grupos Religiosos, Segmento do Comércio, da Educação, Federação das Associações de Moradores do Acre FAMAC. Entre uma regional e outra há diferença nos segmentos representados. $\mathrm{Na}$ regional II não existe o segmento da juventude, que é substituído pelo segmento da Central de Movimentos Populares - CMP

Esses conselhos funcionam como um fórum deliberativo, em que os representantes de cada uma das sete regionais apontam onde e de que forma os recursos devem ser aplicados e investidos. Segundo Aquinei Timóteo (2011), os conselhos deliberam onde os investimentos serão executados por meio do Processo de Gestão Participativo (PGP).

Para Timóteo (2011, p.02) "a finalidade do PGP é a de compartilhar concretamente as decisões e a execução das políticas públicas e ações do 
município, um procedimento que define prioridades e investimentos do orçamento anual por meio de decisão das comunidades". Dessa forma, o PGP seria um avanço e uma superação do modelo de orçamento participativo convencional e teria inúmeras vantagens sobre este.

A principal vantagem, segundo Eduardo Farias (apud TIMÓTEO, 2011), é que o PGP não é um momento orçamentário, mas a permanente e contínua construção de propostas de ação e acompanhamento da execução.

Portanto, os conselhos das regionais foram incorporados à própria organização administrativa da Prefeitura Municipal de Rio Branco, ganhando status de obrigatoriedade de cumprimento das ações eleitas como prioritárias para as regionais, pois os conselhos têm, também, função fiscalizatória e é composto por vários segmentos sociais, garantindo que as prioridades que atingem a maioria dos segmentos sociais recebam atenção especial.

Dessa forma, o OP de Rio Branco esta diretamente relacionado à ascensão do PT ao governo municipal, bem como reúne o implemento de critérios técnicos e políticos na eleição das ações prioritárias e houve uma evolução do atual modelo em relação à primeira experiência, especialmente quanto à estrutura administrativa, já que as regionais foram incorporadas à própria máquina estatal da Prefeitura de Rio Branco. 


\section{CAPÍTULO 5 - RESULTADOS E DISCUSSÃO}

O viés bibliográfico e documental dessa pesquisa permitiu a coleta de alguns dados importantes para a análise do tema em proposto. Procurou-se neste trabalho buscar as experiências com o orçamento participativo em Rio Branco/Ac e, infelizmente, esbarrou-se na ausência de informações nos órgãos públicos consultados.

No entanto, em meio as escassas e assistemáticas informações coletadas, algumas foram obtidas, o que permitiu que a pesquisa fosse viabilizada por meio de um caminho investigativo que, apesar de tortuoso, procurou manter o viés científico da pesquisa. As principais informações advém de jornais eletrônicos, notícias do governo, dados do IBGE e da legislação municipal.

A organização desse conjunto heterodoxo de informações foi muito custosa, contudo, satisfatória aos objetivos proposto neste trabalho. Assim, pode-se chegar resultados a seguir explanados.

O caminho metodológico, as referências bibliográficas, as teorias e os dados coletados apontaram que o Orçamento Participativo, em geral, no Brasil tem três pilares fundamentais, quais sejam a participação popular, a democracia nas escolhas dos representantes comunitários e a não-obrigatoriedade de execução das ações, exceto no município de São Paulo.

De modo geral, o primeiro OP de Rio Branco/Ac, apesar das escassas informações coletadas, seguiu esse padrão e apresentou, por outro lado, ampla politização, o que levou ao mesmo defeito clientelista apontado por Timóteo (2011) para as administrações anteriores ao do Petista Jorge Viana. Sanchez (2002) aponta que justamente o não cumprimento das execuções do OP demonstra a interferência política e o desrespeito às deliberações da sociedade.

Assim, o nível de execução do OP aponta para a manutenção ou não do clientelismo. Os dados coletados por Cordovil (2006), portanto, apontam que o primeiro orçamento participativo de Rio Branco não superou os dilemas do clientelismo e do compadrio.

Isso é notório quando comparadas as cidades de Porto Alegre e Maceió. Ambas, já na década de 80 tinham Orçamento Participativo. No entanto, segundo Sanchez (2002) enquanto quase $90 \%$ (noventa por cento) das ações previstas no 
OP de Porto Alegre foram realizadas, pouco mais de 50\% (cinquenta porcento) das previstas no OP de Maceió chegaram a ser realizadas.

No caso de Rio Branco/Ac a criação das regionais permitiu o incremento dos valores do orçamento participativo conforme os dados coletados no sítio da Prefeitura Municipal de Rio Branco/Acre:

\begin{tabular}{|c|c|c|}
\hline Ano & Valor & Receita do Município \\
\hline 2006 & $\begin{array}{c}10 \text { milhões }(4,5 \% \text { do } \\
\text { Orçamento) }\end{array}$ & 220 milhões \\
\hline 2007 & 13 milhões & \\
\hline 2008 & & 325 milhões \\
\hline 2009 & & 375 milhões \\
\hline 2010 & $\begin{array}{c}15 \text { milhões (3,8\% do } \\
\text { Orçamento) }\end{array}$ & 386 milhões \\
\hline 2011 & & 399 milhões \\
\hline
\end{tabular}

(RIO BRANCO, 2011, p. 01; IBGE, 2011, p. 01)

Tabela 2 - Comparação entre a evolução da Receita do Município de Rio Branco e o percentual de participação do Orçamento Participativo entre os períodos de 2006 a 2010.

No entanto, ressalte-se que os recursos de diversos outros projetos complementam as ações previstas pelas regionais.

Quanto a este modelo, se comparado a outros, apesar de Eduardo Farias citado por Timóteo (2011) dizer que é inovador, nota-se que é muito semelhante aos conselhos regionais das cidades holandesas, já referidos neste trabalho. Contudo, isso não retira o mérito da tentativa de melhorar o modelo de gestão participativa na administração dos recursos públicos.

Contudo, como se vê pela tabela acima, o montante voltado para as ações previstas pelos conselhos regionais caíram percentualmente em relação do orçamento geral do Município, o que indica que o modelo não se mostra mais eficiente que os outros no sentido de democratizar a gestão participativa. Pelo contrário, o decréscimo indica o sentido contrário.

Aliás, a experiência bem sucedida de Porto Alegre caminhou no sentido de aumentar o orçamento participativo e não em diminuí-lo em relação ao Orçamento Geral do Município. Segundo Santos (2002) o percentual do OP de Porto Alegre em 1990 equivalia a 10\% do Orçamento Geral do Município de Porto Alegre e subiu 
para $17 \%$ em 1992 . Isso demonstra o caminho inverso protagonizado pela Prefeitura de Rio Branco.

Dessa forma, conclui-se que o modelo de Rio Branco/Acre em comparação com o seu primeiro OP constitui-se numa inovação que, inclusive, foi considerada entre uma das melhores formas de participação popular na administração brasileira pelo analista.

Entretanto, esse modelo, se por um lado, incorporou de fato a fiscalização das ações previstas pelas populações das regionais, permitindo maior efetividade na execução das ações, o que é de fato uma evolução, por outro lado, os recursos voltados para essas ações não acompanharam a evolução do orçamento do município, o que, obviamente, compromete que os anseios da população sejam cumpridos e permite que o clientelismo continue a grassar na forma como o Poder Público gasta os seus recursos. 


\section{CONCLUSÕES E RCOMENDAÇÕES}

Em sede de conclusão, visualiza-se que o Orçamento Participativo é a concretização da democracia participativa, a qual só encontrou forma a partir dos séculos XIX e XX. Dessa forma, o OP só poderia ter surgido em uma ambiente democrático.

Em verdade, determinados grupos de esquerda imaginou que a gestão participativa poderia até mesmo substituir as formas tradicionais de representação popular, contudo, isso mostrou-se impossível, pois o OP não tem como substituir inteiramente as outras formas tradicionais de representação popular. Sua origem é notadamente vinculada às experiências de esquerda, sendo que no Brasil o partido que incorporou os modelos mais bem avaliados foi o PT, especialmente com a Prefeitura de Porto Alegre.

No caso de Rio Branco, a ascensão do PT na prefeitura de Rio Branco na década de 90 trouxe a primeira experiência com o OP à capital acriana. Contudo, essa experiência não teve continuidade e foi feita de forma desorganizada, de maneira que não há sequer dados arquivados para consulta.

Apesar da ausência de dados, Timóteo (2011) aponta que a experiência foi bem sucedida e que só não houve continuidade devido ao OP não ter sido transformando em obrigatório por meio de leis.

Quanto ao atual modelo, pode-se dizer que ele incorporou os diversos segmentos sociais, possibilitando a ampliação das discussões quanto aos diversos assuntos. Inclusive, cada regional possui grupos voltados para determinados temas como saúde e educação.

Em geral, a forma de divisão da cidade em regional não difere de outros modelos brasileiros de OP. Contudo, não há o estabelecimento de critérios técnicos como densidade populacional ou nível de pobreza de determinada regional, verificados em modelos bem-sucedidos como o de Porto Alegre.

Com efeito, apesar do atual modelo ter sido incorporado na estrutura administrativa da Prefeitura Municipal de Rio Branco, por meio de lei (lei 1551/ 2005, em verdade, persiste a ausência de obrigatoriedade de concretização das ações previstas no OP. Dessa forma, ainda se faz necessário que o OP encontre guarida legal que obrigue o administrador público a cumprir com as ações previstas, de forma de prioritária. 
O sucesso com as experiências de OP, como demonstrado com Porto Alegre e Santo André, está diretamente relacionadas com a obediência aos critérios técnicos, pois as conveniências políticas atuam em sentido contrário às deliberações tomadas no âmbito dos conselhos do OP. Assim, o orçamento participativo deve reunir ao mesmo tempo política e técnica, sendo que os aspectos técnicos como densidade demográfica, nível de pobreza, etc, devem prevalecer sobre os políticos.

Por outro lado, sem dúvida houve um avanço do atual modelo de OP em relação ao primeiro utilizado, contudo, os recursos destinados ao OP reduziram em relação ao Orçamento Geral da Prefeitura de Rio Branco, o que efetivamente contraria a ampliação da gestão participativa dos recursos públicos.

Dessa maneira, urge que o Poder Público garanta que os recursos destinados ao OP aumentem em relação ao Orçamento Geral do Município ou, pelo menos, não decresçam, coisa que, infelizmente, vem acontecendo.

Portanto, apesar das limitações com dados e tempo deste trabalho, pode-se concluir que o atual modelo de gestão participativa de Rio Branco possui vantagens em relação ao primeiro modelo adotado em 1993, mas ainda precisa ser aprimorado para garantir o mesmo nível de recursos, a obrigatoriedade de cumprimento das ações, a continuidade do OP ao longo dos anos.

Mas isso é normal, pois, a experiência com as formas de democracia tradicional mostra que é necessário tempo para que haja amadurecimento, inclusive, é necessário amadurecimento das próprias instituições, que precisam ser cada vez mais transparentes e ouvir as populações envolvidas nas ações realizadas. Dessa forma, os próximos modelos de OP de Rio Branco devem superar esses problemas identificados, privilegiando a democracia participativa. 


\section{REFERÊNCIAS}

ABREU, Julio Cezar Andrade de. Democracia, Hegemonia e internet: um estudo de caso do orçamento participativo digital. Dissertação de mestrado. 150 fls. Universidade Federal da Bahia, Salvador, 2009.

ALEXY, Robert. Teoria de los derechos fundamentales. Madrid, Centro de Estucios Juridicos y constitucionales, 2002.

ALVES, Márcio M. A força do povo: democracia participativa em lages. 5. Ed., São Paulo: Brasiliense, 1980.

AZEVEDO, S. AVRITZER, L. A política do "orçamento participativo": formas de relacionamento entre Estado e sociedade civil. Trabalho apresentado no XVIII Encontro Anual da Anpocs. Caxambu, 23 a 27 de novembro de 1994.

AZEVEDO FILHO, Luiz M. de. Democracia no orçamento Público: orçamento participativo. Disponível em: http://www.arcos.org.br/artigos/democracia-noorcamento-publico-orcamento-participativo/. Acesso em 10. Out. 2011.

BOSI, José Alfredo. Democracia Participativa: alternativa para novos desenhos institucionais. Dissertação de Mestrado, PUC/SP, 2007.

BULOS, Uadi Lammêgo. Constituição Federal Anotada. 3. ${ }^{a}$ ed. São Paulo: Saraiva. 2001

BRASIL.Constituição Federal do Brasil, CF de 1988. Disponível em: http://www.planalto.gov.br/ccivil_03/constituicao/constitui\%C3\%A7ao.htm. Acesso em: 10 out. 2011.

$$
\text { Lei 4.320/64. Disponível em: }
$$

http://www.planalto.gov.br/ccivil_03/leis/L4320.htm. Acesso em: 10 out. 2011.

.Lei Complementar 101. Disponível em: http://www.planalto.gov.br/ccivil_03/leis/LCP/Lcp101.htm. Acesso em: 10 out. 2011.

BRESSER-PEREIRA, Luiz Carlos. Da administração burocrática à gerencial. Disponível em http:www. http://www.scp.rs.gov.br/upload/AdministracaoPublicaGerencial.pdf. Acesso em 10 out. 2011. 
DUTRA, Olívio; BENEVIDES, Maria Victoria. Orçamento Participativo e Socialismo. São Paulo: Fundação Perseu Abramo, 2001.

DWORKIN, Ronald. Levando os direitos à sério. Tradução de Nelson Boeira. São Paulo: Martins Fontes, 2002.

FEDOZZI, Luciano. O poder da aldeia: gênese e história do orçamento participativo de Porto Alegre. Porto Alegre: Tomo Editorial, 2000.

FERNANDES, Rodrigo Barroso; AZEVEDO, Sérgio. O Orçamento Participativo Construindo a Democracia. Rio de Janeiro: Revan, 2005.

FERNANDES, José Henrique P. Porto Alegre: Processo, Projeto e Inserção Internacional. In: PONT, Raul \& BARCELOS, Adair. Porto Alegre: uma cidade que conquista - a terceira gestão do PT no governo municipal. Porto Alegre: Artes e ofício, 2000.

GENRO, Tarso Fernando. 0 futuro por armar: democracia e socialismo na era globalitária. Petrópolis, RJ: Vozes, 1999.

GONÇALVES, Hermes Laranja. Uma Visão Critica do Orçamento Participativo . São Paulo: Lumen Juris , 2005.

IBGE. Cidades do Brasil. Disponível em: http://www.ibge.gov.br/cidadesat/painel/painel.php?codmun=120040. Acesso: 05 out. 2011.

LÜCHMANN, Lígia Helena H.; BORBA, Julian. Orçamento Participativo.. São Paulo: Insular, 2007.

MARQUETTI, Adalmir; CAMPOS, Geraldo Ariano de; PIRES, Roberto. Democracia Participativa e Redistribuição - Análise de Experiências de Orçamento Participativo. Curitiba: XAMA, 2007.

NUNES, Débora. Por uma pedagogia da participação popular. Organizações \& Sociedade, Salvador, V. 6, n. 16, Set/Dez. 1999, p.129-151. 
PIRES, Valdemir. Orçamento participativo: O que é, para que serve, como se faz. São Paulo: Manole, 2001

RIBEIRO, Frank de Paula. Cultura e Participação Popular: mediação política e acesso à moradia na experiência do Orçamento Participativo da Habitação de Belo Horizonte. In: AZEVEDO, Sérgio de; FERNANDES, Rodrigo Barroso (Orgs.). Orçamento Participativo: Construindo a democracia. Rio de Janeiro: Revan, 2005.

RICHARDSON, Roberto Jarry et al. Pesquisa Social: Métodos e Técnicas. 3.ed. São Paulo: Atlas, 1999.

RODRIGUES, Marcelo Abelha. Instituições de Direito Ambiental. São Paulo: Ed. Max Limonad, 2009.

SARUÊ, Roberto Israel E. Superando o caos: descentralização e participação. In: CALDERON, Adolfo, CHAIA Vera (org). Gestão Municipal: descentralização e participação popular. São Paulo: Cortez, 2002.

RÊGO, Marilene Gomes de Sousa A influência da implantação do Orçamento Participativo na Cultura Política dos habitantes da cidade de João Pessoa PB.117f. Dissertação de Mestrado apresentada à Universidade Federal da Paraíba. João Pessoa: 2009. 117f.

RIO BRANCO. Lei 1551. Disponível em http://www.pmrb.ac.gov.br/leisedecretos. Acesso em 10 out. 2011. .www.pmrb.ac.gov.br/notícias. Acesso em 05 out. 2001. Decreto 2.730 . Disponível em http?//www.pmrb.ac.gov.br/leisedecretos.Acesso em 10 out. 2011.

SANTOS, Boaventura de Souza (org.) Democratizar a democracia: os caminhos da democracia participativa. Rio de Janeiro: Civilização Brasileira, 2002.

SANTOS, RITA C. L. Dos. O orçamento público como processo evolutivo. In: Plano Plurianual e orçamento público. Postila do curso de Especialização em Gestão pública à distância da UNB, 2011. Elaboração de Dissertação. 4ª Ed. Florianópolis: Universidade Federal de Santa Catarina, 2005. 
SILVA, José Afonso. Curso de direito constitucional positivo. 23 ed. São Paulo: Editora Malheiros. 2004.

SILVA, Marcelo Kunrath. Construção da participação popular: análise comparativa de processos de participação social na discussão pública de orçamentos nos município da região metropolitana de Porto Alegre. Tese de Doutorado. 295 fls. Universidade Federal do Rio Grande do Sul, Porto Alegre, 2001.

SILVEIRA, Ricardo de Jesus. O significado da participação no poder Local. Cultura Vozes. V. 94, N.5, set./out. 2000, Rio de Janeiro

SOUSA, Marcelo Lopes de.Mudar a cidade: Uma introdução crítica ao planejamento e à gestão urbanos. Rio de Janeiro: Bertrand Brasil, 2002.

WILDAVSKY, Aaron. The new politics of the budgetary process. Second Edition. New York, NY: Harper Collins Publishers, 1992.

TIMÓTEO, Aquinei. Prefeitura organiza reuniões preparatórias para eleição dos conselhos das regionais urbanas. 2011. Disponivel em http://www.riobranco.ac.gov.br/v4/index.php?option=com_content\&view=article\&id=2 182:-prefeitura-organiza-reunioes- reparatorias-para-eleicao-dos-conselhos-dasregionais- rbanas\&catid=1:noticias\&ltemid=68. Acesso em 12 out. 2011.

VERGARA, Sylvia Constant. Projetos e Relatórios de Pesquisa em Administração. 5. ed. São Paulo: Atlas, 2004.

XANGAI, Juracy. Orçamento participativo. In: Jornal Pagina 20. Disponível em http://pagina20.uol.com.br/03012006/c_0303012006.htm. Acesso em 12 out. 2011. 